\title{
耳鼻咽喉科における薬荗耐性（AMR）対策 一司会のことば一
}

\author{
東京北医療センター耳鼻咽喉科／難聴・中耳手術センター \\ 飯野 ゆき子
}

『耐性菌 増やす一言「念のため」』, 『良薬も 飲み方しだいで 悪役に』、『その風邪に ほんとに必要？抗菌薬』. これらは“第 1 回薬剤耐性（AMR）あるある川柳”で金賞と銀賞に選ばれた作品です，非常に重要なメッセージを簡 潔な言葉で表現していると感心しました。この企画はAMR 臨床リファレンスセンターが薬剤耐性 (Antimicrobial resistance：AMR）に関する正しい知識とその対策，そして抗菌薬の適切な使用方法について，国民に理解を深めることを 目的として川柳の公募を行ったものです。この AMR 臨床リファレンスセンターは厚生労働省の委託事業として2017年 4 月に国立国際医療研究センター病院内に設立され，さまざまな観点から AMR 対策を行っている，まさに日本に打け る AMR 拠点とも言うべき施設です.

さて薬剂耐性菌が世界的に増加する現在，新たな抗菌薬の開発は減少傾向にあり，国際社会でも大きな問題となって います. 薬剤耐性（AMR）が拡大した原因の 1 つが抗微生物薬の不適切な使用です. 2013年 AMRに起因する死亡者数 は約70万人とされ，このAMR 問題に対して，なんらかの対策を講じない場合，2050年には1, 000万人の死亡が想定さ れています．この数字は現在のがんによる死亡者数を上まわります．日本の 2013 年のヒトに対する抗菌薬使用量はそれ ほど多くはなく，人口千人当たり 1 日約 15.8 DDD (Defined daily dose（力価）です。これはヨーロッパの先進諸国 の中ではドイツについで低い水準です。しかし黄色ブドウ球菌に占めるメチシリン耐性率や肺炎球菌におけるぺニシリ ン耐性率は，諸外国と比較して高くなっているという現状があります。

本領域講習では感染症対策あるいは抗菌薬使用に造詣の深いお二人の先生に講師を抒願いいたしました．石和田稔彦 先生には総論として AMR 対策が生まれた背景, アクションプランの実際, 今後の展望などを解説していただきます。 また保富宗城先生には耳鼻咽喉科領域の各疾患に扔ける抗菌薬使用の適応, 抗菌薬の選択等をこのアクションプランに そって解説していただきます。

AMR 対策に関する詳しい情報は AMR 臨床リファレンスセンターのホームページにすばらしいウェブサイトがあり ますので，是非アクセスしていただき，より理解を深めていただければと思います. 